
it was the lack of cod that became vexing, with fishermen travelling ever farther offshore for their quarry ${ }^{1}$. Eventually, cod became an infamous cautionary tale of ocean exploitation, and a key target of restoration. The situation varies within New England waters, but one of the most troubled cod stocks, on the Georges Bank, a 29,000-square-kilometre shallow located 100 kilometres off the Cape (see map), stands at just $12 \%$ of restoration goals, which in turn are probably a fraction of historic levels ${ }^{2}$.

For decades, fisheries managers have tried increasingly restrictive methods to rebuild fish populations. In the 1990s, the New England Fisheries Management Council settled on the Days at Sea system. This is a complex series of fishing curbs including limitations on the number of days a fisherman can fish and how much fish can be caught per day, along with various fishing-ground closures. It essentially mandated inefficiency to limit catches and was restrictive enough to slash the number of active fishing boats from about 1,200 in 2001 to roughly 600 by 2009 .

\section{Disaster management}

Some fish populations increased under the Days at Sea policy. However, most people agree that the system didn't work economically. "Days at Sea has been a disaster," says Robert Steneck, a marine ecologist at the University of Maine in Walpole. Jackie Odell, executive director of the Northeast Seafood Coalition, an industry group based in Gloucester, agrees. "People were very frustrated," she says - fishermen and scientists alike.

An even greater incentive to seek a new management system came in 2007, with the reauthorization and revision of the Magnuson-Stevens Fishery Conservation and Management Act, wide-ranging national legislation passed in 1976 to regulate fisheries. New provisions included two ambitious mandates. First, managers had to eliminate overfishing - the practice of taking more than a sustainable level of fish - by 2010, by setting a total allowable catch for each stressed population each year. Second, if a stock is officially overfished - a distinct designation meaning the population is too low to be stable - total allowable catches need to be low enough to allow stocks to rebuild within a decade.

Catch shares began looking more attractive than traditional management structures. One group of fishermen in 2004 got the management council to approve such a programme for cod caught on hook and line on the Georges Bank. In 2006, the pilot programme expanded to include net fishing in the area. In June 2009,

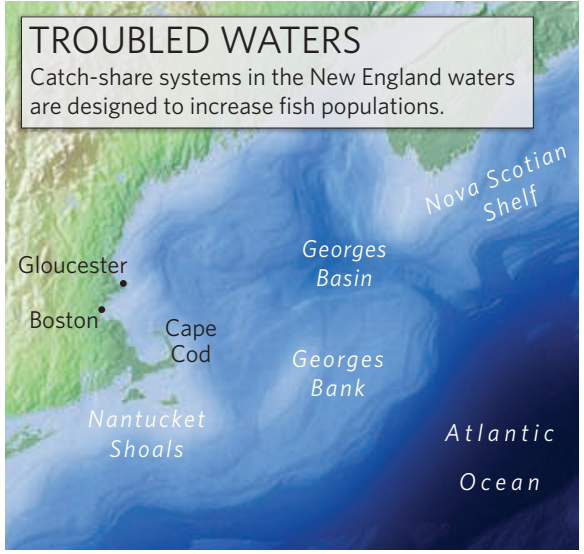

And here, say many, the science is lacking. The Magnuson-Stevens reauthorization dictates that NOAA scientists conduct annual assessments for each managed population. In some cases, assessments were being done about once every five years. And it's doubtful that NOAA currently has the resources to scale up the effort. "That's big science," says Steve Cadrin, a biologist with NOAA's National Marine Fisheries Service based in Woods Hole, Massachusetts and chair of the scientific committee that advises the New England management council. Cadrin says that the agency has proposed relying on multiyear surveys that would set catch limits for a similar amount of time.

the council decided to adopt the scheme as its primary management tool.

Some countries have been adopting and modifying catch-share programmes since the 1970s. Considered a market-based solution, the idea is to minimize the competition for a limited resource by giving individual fishers the right to catch a certain amount of fish. Among the potential benefits, quotas can stabilize fishermen's income and allow them to fill their quotas whenever they like, spreading out fishing efforts. Doing away with season restrictions reduces 'derby' conditions, in which fishermen race out, even in dangerous weather, to catch as much as possible. It also eliminates seasonal market gluts, potentially increasing the prices fishermen can command for their catch. On the ecological side, catch shares can be designed to limit the catch of non-target fish, increase populations of regulated fish and possibly encourage better resource stewardship. Although many catch-share systems are based on giving fishermen individual quotas, the New England council opted for collective sectors in which groups of fishing operations are allotted a quota and can determine what portion of it goes to each sector member.

For the quota system in New England, a major contention is not so much the catch shares themselves, but how the quotas are set.

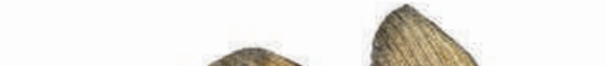
act for NOAA is now a professor at the University of Massachusetts in Dartmouth. He says that the restoration targets for some troubled species are too high and that the ecosystem isn't equipped Cod once dominated the waters off New England. $\begin{array}{r}\text { to handle maximum levels of all } \\ \text { species all the time. "The carry- } \\ \text { ing capacities of ecosystems don't } \\ \text { tion is whether catch shares are the best way } \\ \text { to achieve mandated population restorations }\end{array}$ Cod once dominated the waters off New England. $\begin{array}{r}\text { to handle maximum levels of all } \\ \text { species all the time. "The carry- } \\ \text { ing capacities of ecosystems don't } \\ \text { tion is whether catch shares are the best way } \\ \text { to achieve mandated population restorations }\end{array}$ Cod once dominated the waters off New England. $\begin{array}{r}\text { to handle maximum levels of all } \\ \text { species all the time. "The carry- } \\ \text { ing capacities of ecosystems don't } \\ \text { tion is whether catch shares are the best way } \\ \text { to achieve mandated population restorations }\end{array}$ Cod once dominated the waters off New England. $\begin{array}{r}\text { to handle maximum levels of all } \\ \text { species all the time. "The carry- } \\ \text { ing capacities of ecosystems don't } \\ \text { tion is whether catch shares are the best way } \\ \text { to achieve mandated population restorations }\end{array}$ Cod once dominated the waters off New England. $\begin{array}{r}\text { to handle maximum levels of all } \\ \text { species all the time. "The carry- } \\ \text { ing capacities of ecosystems don't } \\ \text { tion is whether catch shares are the best way } \\ \text { to achieve mandated population restorations }\end{array}$ Cod once dominated the waters off New England. $\begin{array}{r}\text { to handle maximum levels of all } \\ \text { species all the time. "The carry- } \\ \text { ing capacities of ecosystems don't } \\ \text { tion is whether catch shares are the best way } \\ \text { to achieve mandated population restorations }\end{array}$

\section{Stock growth}

Some have also questioned the accuracy of certain current surveys. In New England, ing is going on for 11 species or regionally distinct populations. Even more populations are already low enough to qualify as officially overfished. The New England Fishery Management Council is therefore required by law to drastically lower catch rates in 2010.

Marciano says that the measures being taken don't align with his experience on the water. "If you set the technical definitions of overfishing aside for a minute and look at the stocks overall, you'll see nothing but upward trajectory for the past 15 to 20 years," he says. "There are more fish now than I've seen my entire life." But fishermen have a different perspective from scientists, says Cadrin. "They're out there every day and they know their fishing grounds very well, but they probably don't have as broad a view of all the different areas and different species." For instance, they may not appreciate the importance of rebuilding a variety of stocks if at least some stocks are doing very well. Recent research even suggests that genetic variety within a species is necessary to ensure a secure fishery ${ }^{3}$ (see page 609).

Other scientists, however, find fault with the targets. Brian Rothschild, who oversaw implementation of the original Magnuson-Stevens

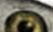

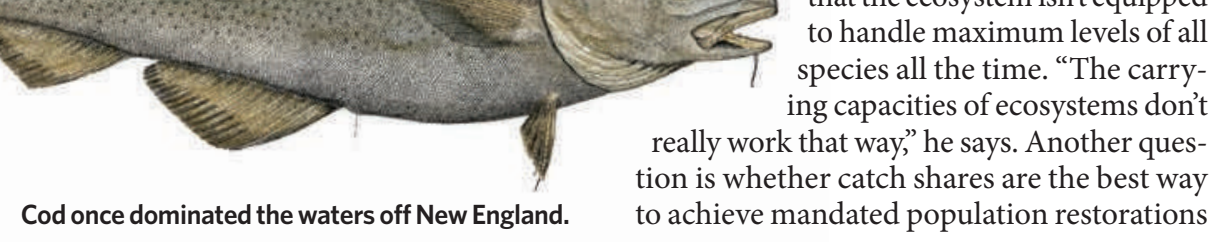


and increased biodiversity. A study ${ }^{4}$ published in 2008 analysed a database of more than 11,000 fisheries, 121 of which were managed using some form of catch shares. The study focused mainly on landings data, and looked for drops in catch as a sign of fishery collapse. The authors concluded that those under catch shares were less prone to collapse and that catch shares can halt or even reverse collapse.

Other studies, using different methods, have suggested a more complicated picture. Timothy Essington, a fisheries ecologist at the University of Washington in Seattle, for instance, looked in more detail at 15 catch-share programmes in North America, analysing their effect on fish numbers, the use of habitat-damaging gear and commercial landings ${ }^{5}$. He found that results varied widely between systems, with continued population declines for some fisheries even under catch share management. "It totally depends on the baseline you're looking at," says Essington.

\section{Rise of the crustaceans}

Steneck, who was part of a task force that examined the catch-share concept for NOAA, says that the scheme could address the loss of diversity in New England's fisheries, which he has studied for more than 20 years. Initially focused on lobsters, he noticed early on that fish such as cod that feed on lobster young were suspiciously scarce. His work has convinced him that the ecosystem may well have shifted into a new state dominated by crustaceans. Even efforts to substantially limit fishing for cod on Georges Bank failed to revive the stocks.

Although he has some reservations, Steneck says that catch shares could be a step in the right direction for fisheries management. "We really have to work on breathing more life into the biodiversity of the marine ecosystem for the good and stability of the populations and also for economic diversity," he says.

One way catch shares may do this is by reducing by-catch - the non-target fish caught and often discarded. Under the Days at Sea system, and most traditional management schemes, the incentive is to catch a lot of fish quickly and there is no individual penalty for by-catch.

Under the catch-share system, fishermen get very small annual quotas for the most troubled species - choke species - and throwing fish overboard becomes illegal. Once the choke species quotas are met, all fishing by the sector has to end, providing a strong incentive for avoiding them, for instance by working with other fishers to identify and avoid areas where choke species are most plentiful. In theory, overexploited species will have a better chance of recovery.

Another oft-touted benefit of catch shares, and one more difficult to prove, is that the system inspires better resource stewardship, including of the habitat on which a fishery depends as nursery and spawning ground. Fishermen might, for example, call for or acquiesce to new protected areas or fishinggear limitations if they think it will improve the resources they share. "I've seen fishermen

will go out of business, but catch-share opponents say it could be $50 \%$ or more, a number many managers and scientists question.

\section{Have to be in it to win it}

Discontent with catch shares isn't universal among independent fishermen. "If you're in it, you think it's great. If you don't have any quota, you think it's terrible," says Larry Huntley, a commercial fisherman based in Pensacola, Florida, where several fledgling catch-share systems are in place. Tom Dempsey, policy coordinator for the Cape Cod
Commercial Hook Fishermen's Association in North Chatham, Massachusetts, which has helped to organize some catchshare sectors, says that because of past problems with Days at Sea, many fishermen he works with are optimistic. "The thinking in town largely is that this is going to help them be more efficient and profitable," he says. He adds, however, that his group still has problems with some of the underlying economics of the system, including a lack of measures to protect against consolidation and monopolies. His group has already started a trust fund to purchase quotas that can then be leased to fishermen who might not

Fisherman Dave Marciano in 1998 (left) and with family in 2007, says that the implementation of catch shares has forced him out of business.

argue for closed areas and no-trawl zones because of the longer-term perspective that catch shares allow," says Rod Fujita, a senior scientist with the Environmental Defense Fund, a non-profit organization, based in San Francisco, California. But Les Watling, a deep-sea ecologist at the University of Hawaii at Manoa, says that anecdote isn't enough. "I haven't seen anything that demonstrates that the industry will protect bottom habitat as a result of catch shares," he says.

Beyond such disputes lies the question of how the catch shares should be distributed. In New England's catch-share system, like most, quotas are determined on the basis of fishing history, but this can cause fairness issues. "The allocation issue really is the tough nut," says Essington. "Chances are there will be winners and losers." Marciano definitely considers himself a loser. Last year he landed almost 36 tonnes of cod, but his quota allocation for this year under catch shares was only 16.8 tonnes. He couldn't afford to buy quotas from others. There are no solid estimates of how many fishermen like Marciano otherwise be able to stay in the system.

Many fishermen and scientists are hoping that the catch-share system will be changed to correct perceived economic inequities and other problems. But politicians aren't always willing to wait. US Representative Barney Frank (Democrat, Massachusetts) is proposing legislation to ease the requirements and timetables of the Magnuson-Stevens reauthorization. Huntley says he fears that such whims may be the greatest threat to the long-term success of rebuilding efforts. In the Gulf of Mexico, for example, in addition to commercial pressure, managers also have to address the concerns of powerful recreational fishing lobbies that have been generally displeased with their allocations under catch-share systems. "What worries me is that politics may outplay the science," says Huntley, "and I don't want to see that."

Mark Schrope is a freelance writer in Melbourne, Florida.

\footnotetext{
1. Steneck, R. S., Vavrinec, J. \& Leland, A. V. Ecosystems 7, 323-332 (2004).

2. Rosenberg, A. A. et al. Front. Ecol. Environ. 3, 78-84 (2005).

3. Schindler, D. E. et al. Nature 465, 609-612 (2010).

4. Costello, C., Gaines, S. D. \& Lynham, J. Science 321, 1678 1681 (2008).

5. Essington, T. E. Proc. Natl Acad. Sci. USA 107, 754-759 (2010).
} 